\title{
Design and Application of Detection Damage Hardware to Your Computer with Certainty Factor
}

\author{
Fitri Ayu, Dwi Sapta Aryatiningsih, Ambiyar, Fahmi Rizal, Anita Febriani
}

\begin{abstract}
In this study, an expert system is used to detect symptoms of damage to computer hardware. With the application of certainty factor models, it is expected to be able to detect symptoms of damage to computer hardware starting with the symptoms of damage from the computer along with solutions for handling the damage. This study aims to produce a fault diagnosis application on web-based computer hardware. This application is expected to make it easier for users to find solutions regarding experienced hardware problems. This expert system application is made using the certainty factor method so that the resulting diagnosis will display symptoms that have more certainty factors. This application was designed using UML and the PHP programming language with black-box testing. The study was conducted by collecting data through literature study, browsing, and interviews. The research method used is the waterfall method. The time of the research is from September 2019 to February 2020. This research is in an application to diagnose damage to computer hardware. Computer Hardware Damage Detection Application can be a guide for computer users in overcoming the damage to hardware with certainty factor methods and can help users in caring for computer hardware so it is not easily damaged.

Keywords: Hardware, Web, PHP, Certainty Factor.
\end{abstract}

\section{INTRODUCTION}

The current use of modern computer technology, namely the development of the field of study Artificial Intelligence (AI) or an AI which is one of the fields of computer science that utilizes computers so that the hardware and software can behave intelligently like humans, which develop [1-3].

One field of AI that mimics processes of human reasoning is expert systems is a program that is enabled to mimic a human expert to be able to do those things that can be done by

Manuscript received on May 28, 2021.

Revised Manuscript received on June 16, 2021.

Manuscript published on June 30, 2021.

* Correspondence Author

Fitri Ayu*, Doctoral Student of Technology and Vocational Education, Universitas Negeri Padang - Indonesia and Lecturer of Information Management, AMIK Mahaputra Riau - Indonesia. Email: fitriayu@amikmahaputra.ac.id

Dwi Sapta Aryatiningsih, Doctoral Student of Technology and Vocational Education, Universitas Negeri Padang - Indonesia and Lecturer of the Study Program of Public Health, STIKes Payung Negeri Pekanbaru Indonesia. Email: dwisapta.aryantiningaih@payungnegeri.ac.id

Ambiyar, Senior lecturers/professors of Technology and Vocational Education, Universitas Negeri Padang - Indonesia: ambiyar@ft.unp.ac.id

Fahmi Rizal, Senior lecturers/professors of Technology and Vocational Education, Universitas Negeri Padang - Indonesia: fahmirizal@ft.unp.ac.id

Anita Febriani, Lecturer of Information Management, AMIK Mahaputra Riau - Indonesia. Email: nitasuheri@gmail.com

(C) The Authors. Published by Blue Eyes Intelligence Engineering and Sciences Publication (BEIESP). This is an open access article under the CC BY-NC-ND license (http://creativecommons.org/licenses/by-nc-nd/4.0/)

an expert [4]. [5] add the system uses the approach with the application of the certainty factors method of certainty which are expected to provide an answer to the user for something uncertain. In this study, an expert system was used to detect symptoms of damage to hardware computers. With the application of the model, it is a certainty factor expected to be able to detect symptoms of damage to hardware computers, starting from symptoms of damage to the computer along with solutions for handling the damage. Based on the above background, the formulation of the problem is as follows: 1 ) ow to make an application that can be a guide for compute a method certainty factor?; and 2) How to make an application that can help users maintain a hardware computer so that it is not easily damaged?

\section{THEORY BASIS}

\section{A. Application}

Applications according to [6] are software created by a computer company to do certain tasks, for example, Microsoft Word, Microsoft Excel. The application comes from the word application which means the application of application for use. According to [7] application is an application, stores things, data, problems, work into a facility or media that can be used to apply or implement existing things or problems so that they turn into a new form without eliminating the basic values of things data, problems, and the work itself. So the application is a transformation from a problem or job in the form of something difficult to understand to become simpler, easier and understandable for the user. So that with the application, a problem will be more quickly and precisely.

\section{B. Artificial Intelligence (AI)}

In this study, an expert system is used to detect symptoms certainty factor models, it is expected to be able to detect symptoms of damage to computer hardware starting with the the computer along with solutions diagnosis application on web-based computer hardware. This application is expected to make it easier for users to find ions regarding experienced hardware problems. This expert system application is made using the certainty factor method so that the resulting diagnosis will display symptoms that have more certainty factors. This application was with black-box testing.




The study was conducted by collecting data through literature study, browsing, and interviews. The research method used is the waterfall method. The time of the research is from September 2019 to February 2020. This research is in an application to diagnose damage to computer hardware. Computer Hardware Damage Detection Application can be a guide for computer users in overcoming the damage to hardware with certainty factor methods and can help users in caring for computer hardware so it is not easily damaged.

\section{Electrical System in Motor}

The expert system is not intended to replace the position of an expert, but to popularize or borrow the knowledge and experience of the expert. Also, the expert system can provide an explanation of the steps taken and provide reasons for the suggestions or conclusions it finds. Expert systems [8] are computer-based applications that are used to solve problems as thought by experts. According to [9] the expert system is designed to be able to solve quite complex problems which only experts can solve. The creation of an expert system is not to replace the expert himself but can be used as a very experienced assistant.

\section{Certainty Factor}

In facing a problem, answers are often found that do not have full certainty. This uncertainty can be in the form of probability or probability depending on the outcome of an event. The results are uncertain due to two factors, namely the rules that are uncertain and the answer uncertainty of a question posed by the system. It is very easily seen in the system. disease diagnosis Experts cannot define the relationship between symptoms and their causes with certainty, and patients cannot feel a symptom with certainty either. In the end, there will be many possible diagnoses. Certainty Factor was introduced by Shortliffe Buchanan in the making of MICIN in 1975 to accommodate the uncertainty of thinking (inexact reasoning) of an expert. Certainty Factor is value clinical parameters given by MYCIN to show the amount of confidence [10].

\section{RESEARCH METHODS}

According to [10-15], the waterfall model is a classic model that is systematic, sequential in building software. The name of the model is the "Linear Sequential Model" model This is often referred to as the "classic life cycle" or the method waterfall. This model is included in the model generic in engineering software and was first introduced by Winston Royce around 1970 so that it is often considered obsolete, but is the most widely used model in Software Engineering (SE). This model takes a systematic and sequential approach. It is called the waterfall because the stages that are passed must wait for the completion of the previous stage and run sequentially. The Phases in the waterfall model according to the [16-20] reference.

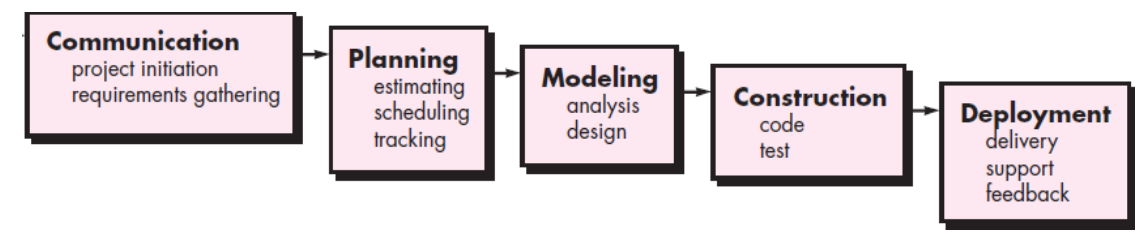

Fig 1. Waterfall Pressman [10]

The stages in this model waterfall areas follows:1) Communication (project initiation \& requirements gathering)_at this stage the researcher communicates with experts to collect the required data. Data collection was carried out in the form of interviews, literature study, and browsing; 2) Planning (estimating, scheduling, tracking)_Stage next researchers time tasks-technical tasks to be performed, the risks that may occur, the resources needed to make the system, the application to generate and scheduling of activities to be implemented; 3) Modeling (analysis \& design)_In the next stage, the researcher conducts system design and modeling that focuses on designing use case diagrams, activity diagrams, interface displays, and algorithms programs. The goal: understanding the big picture for more of what will be done; 4) Construction (code \& test)_At this stage, the researcher conducts coding that implements the design results into code or language that is understood by computer machines using a specific programming language. Testing is done by using black-box that tests performed on the interface(interface)software, testing is done to show that the function-the function works as expected, both entered (input) received and output generated by the system; 5) Deployment (delivery, support, feedback)_At this stage the researcher implements the application, maintains the application periodically.
Application improvement, application evaluation, and application development based on the feedback provided so that the system can continue to run and develop according to its function

\section{ANALYSIS AND DESIGN}

\section{A. Problem analysis problem}

The analysis is the stage to determine what problems must be solved using a multimedia system to be created. To analyze a problem, an analysis of performance, information, economy, application security, efficiency, and services must be carried out. This is described in the analysis Performance, Information, Economy, Control, Efficiency, Service (PIECES).

\section{B. Analysis of system requirements}

Analysis of system requirements is needed to support the application of the system to be built, whether the new system to be implemented is by the needs or following the objectives to be achieved. 


\section{Process analysis}

The problem in diagnosing a damaged hardware computer is in finding information about computer damage that is experienced. With this application, users can more easily consult about the damage to computer hardware they have experienced. The following will explain the process calculation in finding the value certainty of the damage suffered. The Form basic of the formula for a certainty factor of a rule IF E THEN $H$ is as follows:

$$
\mathrm{CF}(\mathrm{H}, \mathrm{e})=\mathrm{CF}(\mathrm{H}, \mathrm{e})^{*} \mathrm{CF}(\mathrm{H}, \mathrm{E})
$$

Description:

CF (E,e): Certainty factor evidence E which is influenced by evidence e

CF $(\mathrm{H}, \mathrm{e})$ : Certainty Factor hypothesis with the assumption of evidence is known with certainty, namely when $\mathrm{CF}(\mathrm{E}, \mathrm{e})=1$ CF (H,e): Certainty factor hypothesis which is influenced by evidence $\mathrm{E}$.

\section{User analysis}

The user is the person who operates the system, the user will utilize and interact with the system. Users who will use the Damage Detection Application Hardware Computers Are as follows: 1) System manager or admin_Admin in damage detection application hardware this computer is a system manager that can change or add to symptoms of damage to hardware computers; 2) Users _Users in damage detection application hardware this computer are users such as general users who can consult about damaged hardware computer experienced.

\section{IMPLEMENTATION AND DISCUSSION}

Input Interface Implementation In this implementation of the section we will discuss the(diagnosis of damage to input interface) user interface application in the computer hardware.

\section{Admin Login Implementation}

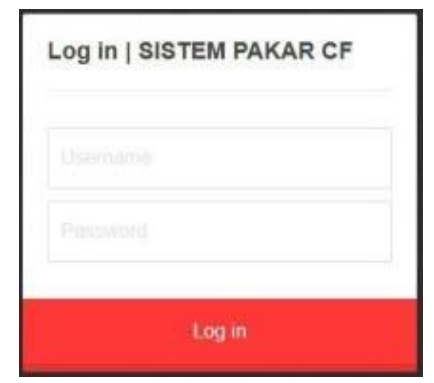

Fig. 1. Admin login display implementation

On this page, the admin must log in first to access and manage the application.

\section{Implementation of Admin Home Page}


Fig. 2. Implementation of Admin

On this page, the admin has successfully logged in and entered the home page. On this page, several menus can be accessed by the admin, including damage data, symptom data, consultation list, knowledge base, user data, consultation, and consultation results.

\section{Damage Data Input Implementation}

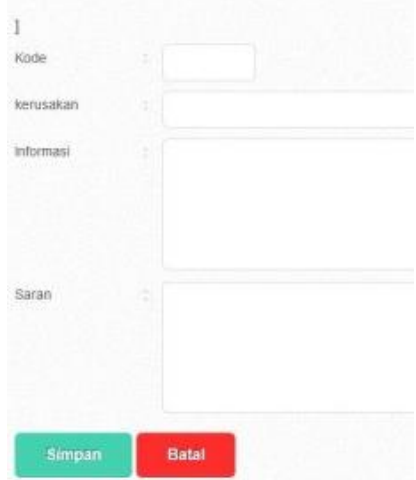

Fig. 3. Damage data input implementation

This page is used to input data on damage to computer hardware. The data input is in the form of code, fault name, information, suggestion.

\section{Output Interface Implementation}

In this section, we will discuss the implementation of the output (output) application user interface diagnostics damage to computer hardware.

\section{Damage Data Output Display Implementation}

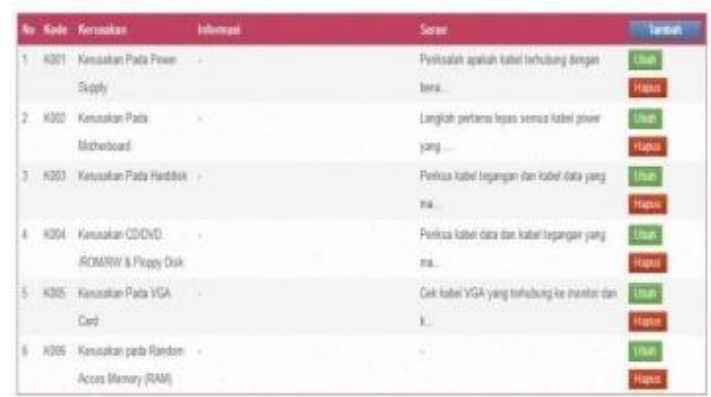

Fig. 4. Display implementation output damage data

This page displays damage data that has been inputted on the damage data input page. The data displayed is in the form of fault codes, fault names, information, and suggestions.

\section{Implementation of Data Output View Damage Symptoms}



Fig. 5. Implementation of data display symptoms damage

Published By:

Blue Eyes Intelligence Engineering

\& Sciences Publication (BEIESP)

30 (C) Copvriaht: All riahts reserved.

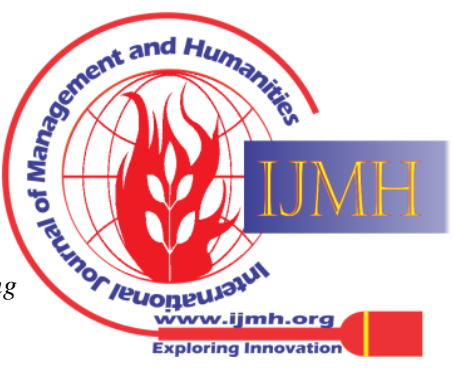


This page displays the data already entered injury symptoms on the symptom data input page. The data displayed is in the form of symptom code, symptom name, and information.

\section{Implementation of Consultation Data Output Display}

\begin{tabular}{|c|c|c|c|c|}
\hline wo Ingye & Innitereglep & Versulan Kanpolst & wa & $\longrightarrow$ \\
\hline 1 21912:23010717 & poil & Kensila Pas VeA and & $80000 \%$ & 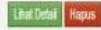 \\
\hline 2. 2219-12:10025211 & Alsyen & 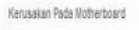 & $52,40 \%$ & Hinces lisas \\
\hline 3. 2194-12:10003623 & $8 m$ & 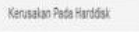 & 60005 & thencal Hows \\
\hline $4 \quad 21919251923194$ & Jener & 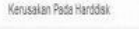 & 700005 & Lasceal has \\
\hline  & Anesobari & 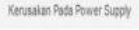 & $10000 \mathrm{x}$ & ynowar haves \\
\hline $62019+12002000517$ & Adn &  & 320005 & Hared has \\
\hline 7. 2019.1201957:49 & Ap & 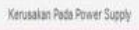 & s0006 &  \\
\hline
\end{tabular}

Fig. 6. Implementation of consultation data display

This page displays data of consultants who have conducted consultations. The data displayed is the date of consultation, the name of the consultant, the damage suffered, and the value of the damage.

\section{CONCLUSION}

Based on the results of research making the application for detecting hardware damage to computers with certainty factors, conclusions can be drawn, namely: 1) This damage detection application hardware computer can be a guide for computer users in overcoming the damage to hardware with methods certainty factor, and 2) This damage detection application hardware computer can assist users in maintaining hardware computer so that it is not easily damaged. For the development of the application for detecting hardware damages on computers with this certainty factor in the future, several suggestions become references, including 1) The development of this application is recommended to have a video tutorial feature for handling problems that occur in hardware computer; and 2) In the future this application is recommended, has a question and answer feature between consultants and experts. This is so that the consultant can ask about the problem being experienced in more detail..

\section{REFERENCES}

1. Y.K Dwivedi, L. Hughes, E. Ismagilova, G. Aarts, C. Coombs, T. Crick, and M.D. Williams. Artificial Intelligence (AI): Multidisciplinary perspectives on emerging challenges, opportunities, and agenda for research, practice and policy. International Journal of Information Management, 2019. 101994.

2. P. Stone, R. Brooks, E. Brynjolfsson, R. Calo, O. Etzioni, G. Hager, and A. Teller. Artificial intelligence and life in 2030: the one hundred year study on artificial intelligence. 2016.

3. M. Satyanarayanan, M. Pervasive computing: Vision and challenges. IEEE Personal communications, 2001. 8(4), 10-17. Kojima. Big data analytics, machine learning, and artificial intelligence in next-generation wireless networks. IEEE access, 2018. 6, 32328-32338.

5. A.E. Saputri, N. Sevani, F. Saputra, and R.K. Sali. Using Certainty Factor Method to Handle Uncertain Condition in Hepatitis Diagnosis. ComTech: Computer, Mathematics and Engineering Applications, 2020. 11(1), 1-10. September 2019, from https://www.academia.edu/4053549/BAB II.

7. Jogiyanto. Analysis \& Design of Information Systems: Approach Yogyakarta

8. Kusrini. Expert System Theory and Applications. 2003. Yogyakarta: Andi Offset.
4. M.G. Kibria, K. Nguyen, G.P. Villardi, O. Zhao, K. Ishizu, and F.

6. Dhanta. Academia Definition of Application. 2015. Accessed on 26 structured to theory and practice. business application. 2013Andi Offset.

9. Kusrini. Expert System Theory and Applications. 2006. Yogyakarta: Andi Offset.

10. D.S. Kusuma. Artificial Intelligence (Techniques and Applications). 2003. Yogyakarta: Graha Ilmu.

11. R. Melyanti. Aplikasi Pengelolaan Keberangkatan Penumpang pada PT. Indah Travel. Jurnal Ilmu Komputer, 7(1), 2018, pp 15-21.

12. R. Melyanti, M. Iqbal. Sistem Informasi Manajemen Penelitian Dan Pengabdian Masyarakat Di Bagian P3m (Studi Kasus: Stmik Hang Tuah Pekanbaru). Jurnal Ilmu Komputer, 9(2), 2020, pp. 165-176.

13. R. Melyanti R, Y. Andreas. Sistem E-wisata pada Dinas Pariwisata di Kota Pekanbaru Berbasis Android. Jurnal Ilmu Komputer, 6(2), 2017, pp. 124-127.

14. H. Hidayati, Suhardi, D. Irfan, A. Ambiyar, R. Melyanti. Sistem Informasi Pelanggaran Siswa Berbasis Web Menggunakan Rapid Application Development. INTECOMS: Journal of Information Technology and Computer Science, 3(2), 2020, pp. 234-242.

15. Rianto, B., Ambiyar, H., Aryantiningsih, D.S., Ayu, F., Rahmiati, S.E. and Melyanti, R.. Utilization of the Google Classroom Application as a Solution to Learning Blood in the Pandemic Time COVID-19. Annals of the Romanian Society for Cell Biology, 2021. pp.13257-13264.

16. R. Pressman. Software Engineering Seventh Edition, 2015. 9-38.

17. H. Ismainar, R. Melyanti, S. Daulay, Y. Irawan, and R. Ordila. Management Information System for Lancang Kuning Hospital Dompet Dhuafa Pekanbaru Using Codeigniter Framework. In Journal of Physics: Conference Series, 2021, 1845(1) p. 012031.

18. Herianto, A. Febriani, R. Melyanti. Sistem Informasi Manajemen Skripsi Mahasiswa Stmik Hang Tuah. Prosiding Seminar Nasional Teknopreneur Universitas Pasir Pengaraian. 1(1), 2018, pp. 253-300.

19. R. Melyanti, D. Irfan, Ambiyar, A. Febriani, R. Khairana. Rancang Bangun Sistem Antrian Online Kunjungan Pasien Rawat Jalan Pada Rumah Sakit Syafira Berbasis Web. INTECOMS: Journal of Information Technology and Computer Science, 3(2), 2020, pp. 192-198.

20. R. Melyanti, D. Irfan, Ambiyar, A. Febriani, R. Khairana, R. Rancang Bangun Sistem Antrian Online Kunjungan Pasien Rawat Jalan Pada Rumah Sakit Syafira Berbasis Web. INTECOMS: Journal of Information Technology and Computer Science, 3(2), 2020, pp. 192-198.

21. R. Melyantri, Herianto. Aplikasi penilaian kinerja dosen dalam Pelaksanaan tri dharma perguruan tinggi. Aplikasi Penilaian Kinerja Dosen Dalam Pelaksanaan Tri Dharma Perguruan Tinggi (Studi Kasus : STMIK Hang Tuah Pekanbaru). 8(10, 2019, pp. 99-106

\section{AUTHORS PROFILE}

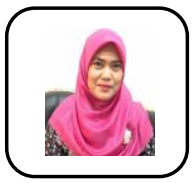

Fitri Ayu is a Doctoral Student of Technology and Vocational Education, Universitas Negeri Padang Indonesia and Lecturer of Information Management, AMIK Mahaputra Riau - Indonesia.

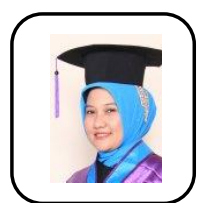

Dwi Sapta Aryantiningsih is a Doctoral Student of Technology and Vocational Education, Universitas Negeri Padang - Indonesia and Lecturer of the Study Program of Public Health, STIKes Payung Negeri Pekanbaru - Indonesia.

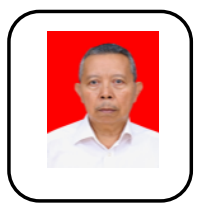

Ambiyar is a Senior lecturers/professors of Technology and Vocational Education, Universitas Negeri Padang Indonesia.

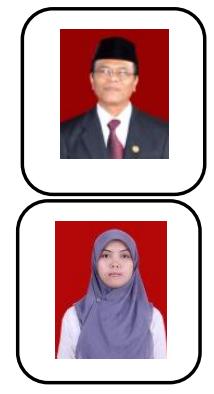

Fahmi Rizal is a Senior lecturers/professors of Technology and Vocational Education, Universitas Negeri Padang - Indonesia.

Anita Febriani, Lecturer of Information Management, AMIK Mahaputra Riau - Indonesia.

Published By:

Blue Eyes Intelligence Engineering \& Sciences Publication (BEIESP)

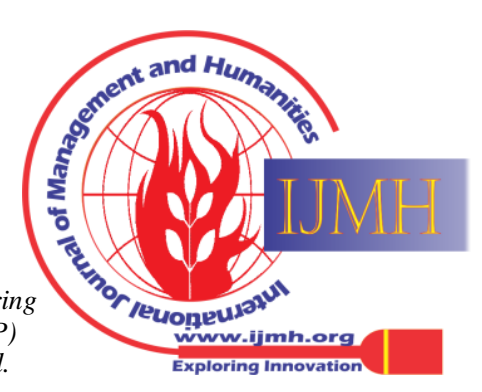

